\title{
Occurrence of Salmonella sp. in poultry carcasses evaluated from the retail trade between 2007 and 2013 in Paraná state, Brazil
}

\section{Ocorrência de Salmonella sp. em carcaças de frango avaliadas a partir do comércio varejista entre 2007 e 2013 no estado do Paraná, Brasil}

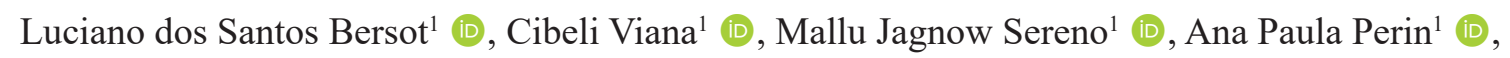 \\ Vinicius Cunha Barcellos ${ }^{1}$ (it) \\ ${ }^{1}$ Universidade Federal do Paraná, Setor Palotina, Departamento de Ciências Veterinárias, Laboratório de Inspeção e Controle de Qualidade de \\ Alimentos e Água, Palotina - PR, Brazil

\begin{abstract}
Poultry meat is often involved as a vehicle for microorganisms that cause food-borne diseases. Salmonella sp. is a major pathogen involved in outbreaks around the world. Based on its importance, the objective of this study was to determine the occurrence of Salmonella sp. in frozen and chilled poultry carcasses slaughtered and marketed in the western region of Paraná state, Brazil. A total of 340 samples were collected between January 2007 and April 2013, with 66 (19.41\%) carcasses positive for Salmonella sp. It can be concluded from the results obtained that the occurrence of Salmonella sp. in poultry carcasses remains high, even though it is a product marketed refrigerated or frozen, methods considered appropriate for food preservation. A lower occurrence result was expected due to the 14-year implementation of the national pathogen reduction program established by the Ministry of Agriculture, Livestock and Supply aimed at a gradual reduction in the occurrence of Salmonella sp. in these products through constant monitoring of carcasses immediately after slaughter.
\end{abstract}

Keywords: Chilled carcass. Frozen carcass. Poultry slaughter. Occurrence. PRP.

\section{RESUMO}

A carne de aves é um alimento que frequentemente encontra-se envolvido como veículo de micro-organismos causadores de enfermidades, sendo Salmonella sp. um desses agentes comumente envolvidos nessas enfermidades em todo o mundo. Com isso, o objetivo deste estudo foi determinar a ocorrência de Salmonella sp. em carcaças de frango congeladas e refrigeradas, abatidas e comercializadas na região oeste do estado do Paraná. Um total de 340 amostras foram coletadas entre janeiro de 2007 e abril de 2013. Das amostras analisadas, 66 (19,41\%) das carcaças foram positivas para Salmonella sp. De acordo com os resultados obtidos pode-se concluir que a ocorrência de Salmonella sp. em carcaças de frangos permanece alta, mesmo sendo produtos comercializados refrigerados ou congelados, métodos considerados adequados para conservação de alimentos. Um resultado de menor ocorrência era esperado devido à implementação de 14 anos do Programa Nacional de Redução de Patógenos estabelecido pelo Ministério da Agricultura, Pecuária e Abastecimento visando uma redução gradual na ocorrência de Salmonella sp. nestes produtos através de monitoramento constante de carcaças imediatamente após o abate.

Palavras-chave: Carcaças resfriadas. Carcaças congeladas. Abate de aves. Ocorrência. PRP.

Correspondence to:

Luciano dos Santos Bersot

Universidade Federal do Paraná, Setor Palotina, Departamento de Ciências Veterinárias, Laboratório de Inspeção e Controle de Qualidade de Alimentos e Água

Rua Pioneiro, 2153, Jardim Dallas

CEP: 85950-000, Palotina - PR, Brazil

e-mail: lucianobersot@gmail.com

Received: September 20, 2018

Approved: February 04, 2019
How to cite: Bersot LS, Viana C, Sereno MJ, Perin AP, Barcellos VC. Occurrence of Salmonella sp. in poultry carcasses evaluated from the retail trade between 2007 and 2013 in Paraná state, Brazil. Braz J Vet Res Anim Sci. 2019;56(2):e150446. https://doi.org/10.11606/issn.16784456.bjvras.2019.150446

\section{Introduction}

Brazil holds a prominent position in poultry production, being the largest exporter and the third largest producer of poultry meat in the world. In 2016, the country was 
responsible for the slaughter of 5.86 billion birds, with Paraná state the main national producer, with 1.83 billion birds slaughtered (Associação Brasileira de Proteína Animal, 2016; Instituto Brasileiro de Geografia e Estatística, 2016). The recognition reached by the country in the poultry market stems from continuous advances in production methods, genetic improvement, plant health management and control of slaughter processes, including the monitoring and control of Salmonella sp.

Despite constant effort of the poultry industry to ensure the safety of the food produced, the presence of Salmonella sp. is still significant, representing one of the industry's biggest concerns. The contamination of poultry meat by Salmonella sp. can occur at different steps of the production chain. Some operations, such as scalding, plucking and evisceration, are considered critical because they move a great biological load, playing a fundamental role in the microbial contamination of carcasses and their derivatives (Boni et al., 2011; Von Ruckert et al., 2009). The control of Salmonella sp. is a challenge faced not only by Brazil. Studies carried out in several countries indicate a high prevalence of the agent in poultry meat and in slaughter environments, demonstrating the relevance of this pathogen in the world poultry scene (Álvarez-Fernández et al., 2012; Donado-Godoy et al., 2012; Hue et al., 2011; Medeiros et al., 2011; Sakaridis et al., 2011; Zhu et al., 2014).

Considering the epidemiological importance Salmonella sp. has in poultry, since 2003, the Ministry of Agriculture, Livestock and Food Supply (MAPA) has been monitoring the presence of the pathogen in carcasses immediately after slaughter through the "Pathogen Reduction Program" (PRP). It was established by the Normative Instruction (IN) 70 (Brasil, 2003a) and replaced in 2016 by IN 20, with the aim of ensuring a gradual reduction of the occurrence of Salmonella sp. through constant monitoring of sampling cycles, and to establish an adequate level of consumer protection. According to the legislation, in industries with slaughter volume exceeding 100,000 birds / day, it establishes acceptable limits of 12 positive samples for Salmonella sp. in a sampling cycle of 51 carcasses (Brasil, 2016). Through this monitoring, it is possible to identify the industries with high occurrence and to make impact actions with the objective of ensuring acceptable limits of contamination.

After more than a decade since monitoring by the PRP began, a reduction of the occurrence of pathogens in poultry carcasses slaughtered are expected in Brazil. However, the PRP occurrence data, as an official monitoring, are not available to the scientific community and the general population, making it impossible to know if the program is actually effective in reducing Salmonella sp. in poultry carcasses and if there has been a reduction of the population exposure by this pathogen.

Thus, the monitoring of PRP occurrence and effectiveness data has been done indirectly by research laboratories of higher education institutions through analysis of products exposed to the sale, since this is the data are available for consultation. Based on this, the objective of this study was to compile the occurrence data of Salmonella sp. in a 7-year period (between 2007 and 2013) of chilled and frozen carcass samples exposed in the retail trade in the state of Paraná, indirectly monitoring the effectiveness of the PRP.

\section{Materials and Methods}

Between January 2007 and April 2013, 340 poultry carcass samples were analyzed, all of them commercialized in the western region of state of Paraná, in the cities of Assis Chateaubriand, Toledo, Marechal Cândido Rondon and Palotina. Whole carcasses, frozen (200) or refrigerated (140), from different brands and lots were purchased in grocery stores and supermarkets randomly selected, the way they were exposed to the consumers. At the moment of the acquisition to select the samples, the following instructions were required: the samples were with their packages intact, which were within the validity period and identified by the Federal Inspection Service (SIF), the agency of MAPA responsible for fiscal action in slaughterhouses and establishments of processing animal products.

The carcasses were placed inside a thermal box containing recyclable ice and transported to the Laboratory of Inspection and Control of Quality of Food and Water, Department of Veterinary Sciences, Federal University of Paraná, Palotina. All samples were submitted for the isolation of Salmonella sp. in $25 \mathrm{~g}$, according to the methodology recommended by Normative Instruction 62 of MAPA, with modifications (Brasil, 2003b).

For the pre-enrichment stage, $25 \mathrm{~g}$ of each carcass (portions of skin and muscle from the chest, wings, neck and cloaca region) were collected and packed in a sterile plastic bag, and then $225 \mathrm{~mL}$ of buffered peptone water $1 \%$ was added. The samples were homogenized for $1 \mathrm{~min}$ in stomacher (Seward, England) and incubated at $35-37^{\circ} \mathrm{C}$ for 18-24 h in a bacteriological oven.

For the selective enrichment, tetrathionate (TT) broth with $0.01 \%$ novobiocin, Rapapport-Vassiliadis (RV) broth and 
selenite-cystine (SC) broth were used. From the pre-enriched samples, aliquots of $1 \mathrm{~mL}, 0.1 \mathrm{~mL}$ and $1 \mathrm{~mL}$ were transferred to the TT, RV and SC broth, respectively. All broths were incubated in a water bath at $42 \pm 0.2^{\circ} \mathrm{C}$ for $24 \mathrm{~h}$.

From each of the selective enrichment broths, one loop was streaked onto selective plates containing xylose lysine deoxycholate, green-brilliant red phenol and bismuth sulfite. All plates were incubated at $35^{\circ} \mathrm{C}$ for $24 \mathrm{~h}$. After incubation, 3-5 colonies typical of Salmonella sp. of each plate were transferred to tubes containing triple iron agar and lysine iron agar, both incubated at $35^{\circ} \mathrm{C}$ for $24 \mathrm{~h}$.

The isolates showing a characteristic reaction for Salmonella sp. were subjected to the serum agglutination test in the lamina, using flagellar $(\mathrm{H})$ and somatic $(\mathrm{O})$ polyvalent antiserum. Cultures with positive reactions (agglutination) were submitted to the biochemical characterization of urea, indole, methyl red, Voges-Proskauer, citrate and malonate.

The data were submitted to Kruskal-Wallis non-parametric analysis (PROC NPAR1WAY), in which the effect of year of sampling was tested at the $5 \%$ level of significance. Means were compared by the Tukey-Kramer test (PROC MEANS). The analyses were performed in the program Statistical Analysis System, version 9.0.

\section{Results and Discussion}

Of the total carcasses analyzed between 2007 and 2013 $(\mathrm{n}=340)$, in $66(19.41 \%)$, the presence of Salmonella sp. was confirmed. The number of carcasses sampled per year and the results are shown in Table 1, where an occurrence pattern is observed increasing between the years, from $11.67 \%$ in 2007 to $35 \%$ in 2013.

Based on the results, we realized the occurrence pattern was increasing between the years. However, this scenario was reversed in other countries when we observed some studies where the authors pointed to a decrease in the prevalence of Salmonella sp. over the years (Álvarez-Fernández et al., 2012; Dan et al., 2015). This reduction, evidenced in some countries, may be due to the adoption of a set of mandatory measures developed to control and reduce Salmonella sp., such as tracking and surveillance of breeders and hatcheries; vaccination of herds against some serotypes, and introduction of HACCP - Hazard Analysis Systems and Critical Control Points in processing plants (Álvarez-Fernández et al., 2012).

Although Brazil also adopts the same measures previously mentioned, and all samples were processed in establishments inspected by Federal Inspection Service, the results of this research evidenced, in addition to the increase over the years, the detection of a high percentage of Salmonella sp. on carcasses. It is important to emphasize that a slaughterhouse certified by Federal Inspection Service must ensure the implementation and monitoring of quality control protocols according to the HACCP program. In addition, this federal certification allows these establishments to export their products.

While official data obtained by the PRP were not made available periodically for review by the general population, since the implementation of the program, there was only one official disclosure through a Technical Note issued in 2010. This Technical Note reports a prevalence of Salmonella sp. of $6.4 \%$, obtained through the analysis of 128,293 poultry carcasses between 2003 and 2008 (Brasil, 2010). This is a significantly lower percentage when compared to the results obtained in this study (Table 1), even when considering only the data obtained in the same period that involved the official analyses (2007 and 2008).

One factor that may explain the high positivity index found is that the samples analyzed in this study were obtained directly from the retail market. This is different from PRP, where the samples obtained for official analysis should be obtained from the slaughter, collected immediately after the drip (Brasil, 2016). According to Possebon et al. (2012), there has been a tendency of the samples obtained from the retail to present a greater positivity than the carcasses

Table 1 - Contamination of poultry carcass samples by Salmonella sp. analyzed between 2007 and 2013 - Palotina, 2017

\begin{tabular}{|c|c|c|c|c|c|}
\hline \multirow{3}{*}{ Year } & \multirow{3}{*}{$\begin{array}{c}\text { Total Sample } \\
\text { (n) }\end{array}$} & \multicolumn{4}{|c|}{ Contamination } \\
\hline & & \multicolumn{2}{|c|}{ Sample (n) } & \multicolumn{2}{|c|}{ Frequency(\%) } \\
\hline & & Negative & Positive & Negative & Positive \\
\hline 2007 & 60 & 53 & 7 & $88.33^{a}$ & $11.67^{b}$ \\
\hline 2008 & 120 & 103 & 17 & $85.83^{\mathrm{a}}$ & $14.17^{b}$ \\
\hline 2009 & 60 & 49 & 11 & $81.67^{\mathrm{ab}}$ & $18.33^{\mathrm{ab}}$ \\
\hline 2012 & 60 & 43 & 17 & $71.67^{\mathrm{ab}}$ & $28.33^{\mathrm{ab}}$ \\
\hline 2013 & 40 & 26 & 14 & $65.00^{b}$ & $35.00^{\mathrm{a}}$ \\
\hline Mean & & & & 80.59 & 19.41 \\
\hline P valuel & & & & & \\
\hline
\end{tabular}

IProbability value for Kruskal-Wallis non-parametric test; Averages followed by different lowercase letters in the same column differ by the Tukey test ( $<<0,05)$. 
collected soon after the precooling stage. This difference was observed by Fletcher (2006), who detected a 21.6\% increase in the positivity of samples collected in retail when compared to the industry.

Therefore, the time the samples are collected to perform the detection of Salmonella sp. can influence the results of the analyses. The industry applies several treatments during slaughter that could injure the microbial cells present in the carcasses, such as the use of successive rinses of the whole carcass with chlorinated water, the use of antimicrobial agents and the presence of chlorine residual in the samples, thus hindering the microbial isolation (Fletcher, 2006). Still, some countries are permitted to use some substances with antimicrobial potential directly in the carcass, a practice not allowed in Brazil, according to current legislation (Brasil, 1998).

In addition, in retail, for preservation of the product, the carcasses are kept refrigerated or frozen. However, some microorganisms can produce defense mechanisms in response to the temperature oscillation. Among these mechanisms, the most effective are the expression of specialized proteins (which increase the resistance to thermal shock), the change in membrane structure (change in saturation of fatty acids to protect against low temperatures) and the repair of genetic material (Everis, 2001). All these factors, associated or individually, have already verified the resistance of Salmonella sp. at a temperature of $-20^{\circ} \mathrm{C}$ for 26 weeks (Dominguez \& Schaffner, 2009; Strawn \& Danyluk, 2010).

Another factor that may influence the evaluation of the effectiveness of the PRP in Brazil concerns the methodology used in this research. We aimed to investigate the presence or absence of microorganisms of the Salmonella genus, without differentiation of the serotypes. Nevertheless, the measures implemented by the National Poultry Health Program (PNSA) and the PRP had some specific serotypes of this pathogen, such as Gallinarum, Pullorum, Enteritidis and Typhimurium. Some studies have shown that after the implementation of these control measures established by these programs the decline of these serotypes occurred (Kottwitz et al., 2013; Voss-Rech et al., 2015; Mion et al., 2016). However, as a reflection of a competitive exclusion, the emergence and reemergence of new serotypes may explain the reason the occurrence of Salmonella sp. still remains high in the poultry chain (Ribeiro et al., 2007; Rall et al., 2009; Yamatogi et al., 2012; Fernandes et al., 2016), corroborating with the high occurrence observed in this work.
This scenario was verified in Brazil in the early 2000s when the main serotype described in chicken meat samples was $S$. Enteritidis, with percentages reaching up to $84 \%$ when compared to the other serotypes (Costa et al., 1997; Santos et al., 2000; Kanashiro et al., 2005; Ribeiro et al., 2007). This serotype was prominent in the country after the Gallinarum and Pullorum serotypes were controlled (Rabsch et al., 2001). However, data compiled by Kottwitz et al. (2013) show that, in the following years, there was a decline of $S$. Enteritidis in biological samples of chicken, which fell from $77 \%$ in 2006 to $9 \%$ in 2010 , demonstrating the control of this serotype.

This behavior is probably a reflection of the implementation of the National Control Programs of Salmonella sp., especially of the PNSA. This program determined the slaughter of matrices with $S$. Gallinarum and $S$. Pullorum and the vaccination of batches of breeding birds with inactivated vaccines against $S$. Enteritidis. This immunoprophylaxis started in 2003 and may have helped reduce the prevalence of this serotype in broilers (Brasil, 2003c). With S. Gallinarum, $S$. Pullorum and $S$. Enteritidis under control, new serotypes may find favorable conditions for their maintenance in the poultry breeding environment.

Several methodologies have been developed and used, which, in addition to phenotypic serotyping, become important supports to epidemiological data. However, comprehensive occurrence studies are important tools for overall identification of Salmonella sp. contamination in poultry products. This makes it possible to evaluate the need to update and improve existing health programs, since this microorganism is still the main agent associated with foodborne illnesses in Brazil. The control of Salmonella sp. is essential for the entire production chain and for guaranteeing an innocuous food.

\section{Conclusion}

It was possible to verify that the occurrence of Salmonella sp. has increased over the years in samples obtained in the retail trade even after more than a decade of implementation of the PRP in poultry slaughter, established by MAPA. Even considering the reasons that are able to justify the higher occurrence in samples collected from retail trade than those from slaughterhouse, it is important to verify the possibility of crossing the data obtained in commercial samples with those of official PRP data. Thus, it is possible to evaluate the impact of this program with the reduction of Salmonella sp. to the consumer and, consequently, to the reduction of the risk of the occurrence of salmonellosis carried by this type of food. 
In addition, further studies should use other methodologies, such as phenotypic serotyping, to evaluate the effectiveness of the PRP once it determines controls for some specific serotypes in farms. Based on these kinds of tests, it would at least be possible to evaluate if the occurrence of serotypes is dwindling. However, if the global occurrence doesn't decrease significantly, it may be due to new serotypes finding favorable conditions for their maintenance in the poultry breeding environment. Thus, it is important to evaluate the need to expand the control measures programs for other serotypes along with the serotypes included in the PNSA.

\section{References}

ABPA: Associação Brasileira de Proteína Animal [Internet]. Relatório anual. São Paulo: ABPA; 2016 [cited 2017 May 20] Available from: http://abpabr.com.br/storage/files/ abpa_relatorio_anual_2016_ingles_web_versao_para_ site_abpa_bloqueado.pdf

Álvarez-Fernández E, Alonso-Calleja C, GarcíaFernández C, Capita R. Prevalence and antimicrobial resistance of Salmonella serotypes isolated from poultry in Spain: comparison between 1993 and 2006. Int J Food Microbiol. 2012;153(3):281-7. http://dx.doi.org/10.1016/j. ijfoodmicro.2011.11.011. PMid:22208955.

Boni HFK, Carrijo AS, Fascina VB. Ocorrência de Salmonella spp. em aviários e abatedouros de frangos de corte na região central do Mato Grosso do Sul. Rev Bras Saúde Prod Anim. 2011;12(1):84-5.

Brasil. Ministério da Saúde. Instrução Normativa ${ }^{\circ}$ 1.004, de 11 de dezembro de 1998. Aprova o regulamento técnico: "Atribuição de Função de Aditivos, Aditivos e seus Limites Máximos de uso para a Categoria 8 - Carne e Produtos Cárneos". Diário Oficial da União; Brasília; 1998 Dec 11.

Brasil. Ministério da Agricultura, Pecuária e Abastecimento. Instrução Normativa n ${ }^{\circ} 70$, de 06 de outubro de 2003. Institui o Programa de Redução de Patógenos, Monitoramento Microbiológico e Controle de Salmonella sp. em carcaças de frangos e perus. Diário Oficial da União; Brasília; 2003a Out 06.

Brasil. Instrução Normativa no 62, de 26 de agosto de 2003. Métodos analíticos oficiais para análises microbiológicas para controle de produtos de origem animal e água. Diário Oficial da União; Brasília; 2003b Ago 26.

\section{Conflict of Interest}

The authors state that they have no conflicts of interest to declare.

\section{Ethics Statement}

Not applicable.

\section{Acknowledgements}

Not applicable.
Brasil. Instrução Normativa $n^{\circ} 78$, de 3 de novembro de 2003. Aprovar as normas técnicas para controle e certificação de núcleos e estabelecimentos avícolas como livres de Salmonella Gallinarum e de Salmonella Pullorum e livres ou controlados para Salmonella Enteritidis e para Salmonella Typhimurium, em anexo. Diário Oficial da União; Brasília; 2003c Nov 03.

Brasil. Ministério da Agricultura, Pecuária e Abastecimento. Nota Técnica. Divulgação dos resultados do banco de dados gerado a partir da implantação da Instrução Normativa $\mathrm{n}^{\mathrm{o}} 70$, de 6 de outubro de 2003. Brasília: Ministério da Agricultura, Pecuária e Abastecimento; 2010.

Brasil. Instrução Normativa ${ }^{\circ} 20$, de 21 de outubro de 2016. Controle e monitoramento de Salmonella spp. nos estabelecimentos avícolas comerciais de frangos e perus de corte e nos estabelecimentos de abate de frangos, galinhas, perus de corte e reprodução, registrados no Serviço de Inspeção Federal (SIF). Diário Oficial da União; Brasília; 2016 Out 21.

Costa FN, Rossi OD Jr, Nader A Fo, Tavechio AT. Sorovares de Salmonella isolados de carcaças e cortes de frango obtidos na indústria e no comércio em Jaboticabal, Estado de São Paulo, em 1996. Rev Bras Med Vet. 1997;4(3):97-100. http:// dx.doi.org/10.4322/rbcv.2015.082.

Dan S, Tabaran A, Mihaiu L, Mihaiu M. Antibiotic susceptibility and prevalence of foodborne pathogens in poultry meat in Romania. J Infect Dev Ctries. 2015;9(1):3541. http://dx.doi.org/10.3855/jidc.4958. PMid:25596569.

Dominguez SA, Schaffner DW. Survival of Salmonella in processed chicken products during frozen storage. J Food Prot. 2009;72(10):2088-92. http://dx.doi.org/10.4315/0362028X-72.10.2088. PMid:19833031. 
Donado-Godoy P, Clavijo V, León M, Tafur MA, Gonzales S, Hume M, Alali W, Walls I, Lo Fo Wong DM, Doyle MP. Prevalence of Salmonella on retail broiler chicken meat carcasses in Colombia. J Food Prot. 2012;75(6):1134-8. http:// dx.doi.org/10.4315/0362-028X.JFP-11-513. PMid:22691484.

Everis L. Injured bacteria in foods. Int J Food Sci Nutr. 2001;31(2):84-7. http://dx.doi.org/10.1108/00346650110367008.

Fernandes RTV, Arruda AMV, Costa MKO, Lima PO, Santos LOG, Melo AS, Marinho JBM. Physicochemical and microbiological parameters of frozen and chilled chicken meat. Rev Bras Zootec. 2016;45(7):417-21. http://dx.doi. org/10.1590/S1806-92902016000700009.

Fletcher DL. Influence of sampling methodology on reported incidence of Salmonella in poultry. J AOAC Int. 2006;89(2):512-6. PMid:16640301.

Hue O, Le Bouquin S, Lalande F, Allain V, Rouxel S, Petetin I, Quesne S, Laisney MJ, Gloaguen PY, Picherot M, Salvat G, Bougeard S, Chemaly M. Prevalence of Salmonella spp. on broiler chicken carcasses and risk factors at the slaughterhouse in France in 2008. Food Control. 2011;22(8):1158-64. http:// dx.doi.org/10.1016/j.foodcont.2011.01.009.

IBGE: Instituto Brasileiro de Geografia e Estatística [Internet]. Indicadores da produção agropecuária. Rio de Janeiro: IBGE; 2016 [cited 22 May 2017]. Available from: https://biblioteca.ibge.gov.br/visualizacao/periodicos/2380/ epp_2016_4tri.pdf

Kanashiro AMI, Stoppa GFZ, Cardoso ALSP, Tessari ENC, Castro AGM. Serovars of Salmonella spp. isolated from broiler chickens and commercial breeders in diverse regions in Brazil from July 1997 to December 2004. Rev Bras Cienc Avic. 2005;7(3):195-8. http://dx.doi.org/10.1590/ S1516-635X2005000300010.

Kottwitz LBM, Back A, Leão JA, Frausto HSEG, Magnani M, Oliveira TCRM. Decline of Salmonella Enteritidis in poultry. Br Food J. 2013;115(11):1541-6. http://dx.doi. org/10.1108/BFJ-04-2012-0086.

Medeiros MA, Oliveira DCN, Rodrigues DP, Freitas DRC. Prevalence and antimicrobial resistance of Salmonella in chicken carcasses at retail in 15 Brazilian cites. Rev Panam Salud Publica. 2011;30(6):555-60. http://dx.doi.org/10.1590/ S1020-49892011001200010. PMid:22358402.

Mion L, Parizotto L, Santos LA. Salmonella spp. isolated by miniaturized most probable number and conventional microbiology in poultry slaughterhouses. Acta Sci Vet. 2016;44:1-5.

Possebon FS, Costa LF, Yamatogi RS, Rodrigues MV, Sudano MJ, Pinto JPAN. A refrigeração no diagnóstico de Salmonella spp. utilizando o método microbiológico tradicional e reação em cadeia da polimerase em carcaças de frango. Cienc Rural. 2012;42(1):131-5. http://dx.doi. org/10.1590/S0103-84782011005000154.

Rabsch W, Tschape H, Baumler AJ. Non-typhoid salmonellosis: emerging problems. Microbes Infect. 2001;3(3):237-47. http:// dx.doi.org/10.1016/S1286-4579(01)01375-2. PMid:11358718.

Rall VLM, Martin JGP, Candeias JMG, Cardoso KFG, Silva MG, Rall R, Araújo JP Jr. Pesquisa de Salmonella e das condições sanitárias em frangos e linguiças comercializados na cidade de Botucatu. Braz J Vet Res Anim Sci. 2009;46(3):167-74. http://dx.doi.org/10.11606/issn.1678-4456.bjvras.2009.26763.

Ribeiro AR, Kellermann A, Santos LR, Bessa MC, Nascimento VP. Salmonella spp. in raw broiler parts: occurrence, antimicrobial resistance profile and phage typing of the Salmonella Enteritidis isolates. Braz J Microbiol. 2007;38(2):2969. http://dx.doi.org/10.1590/S1517-83822007000200021.

Sakaridis I, Soultos N, Issofidou E, Koidis P, Ambrosiadis I. Prevalence and antimicrobial resistance of Salmonella serovars from chicken carcasses in northen Greece. J Food Saf. 2011;31(1):203-10. http://dx.doi.org/10.1111/j.17454565.2010.00286.x.

Santos DMS, Berchieri A, Fernandas SA, Tavechio AT, Amaral LA. Salmonella em carcaças de frango congeladas. Pesq Vet Bras. 2000;20(1):39-42. http://dx.doi.org/10.1590/ S0100-736X2000000100005.

Strawn LK, Danyluk MD. Fate of Escherichia coli O157:H7 and Salmonella spp. on fresh and frozen cut mangoes and papayas. Int J Food Microbiol. 2010;138(1-2):78-84. http:// dx.doi.org/10.1016/j.ijfoodmicro.2009.12.002. PMid:20022397.

Von Rückert DAS, Pinto PSA, Santos BM, Moreira MAS, Rodrigues ACA. Pontos críticos de controle de Salmonella spp. no abate de frangos. Arq Bras Med Vet Zootec. 2009;61(2):326-30. http://dx.doi.org/10.1590/S010209352009000200007.

Voss-Rech D, Vaz CSL, Alves L, Coldebella A, Leão JA, Rodrigues DP, Back A. A temporal study of Salmonella enterica serotypes from broiler farms in Brazil. Poult Sci. 2015;94(3):433-41. http://dx.doi.org/10.3382/ps/peu081. PMid:25595481. 
Yamatogi RS, Padovani CR, Galvão JA, Bersot LS, Pinto JPAN. Salmonella spp. in poultry carcass: evaluation of sample preparation methods and effect of storage under refrigeration on pathogen recovery. Microbiol Res. 2012;3(1):50-3. PMid:22819383.

Zhu J, Wang Y, Song X, Cui S, Xu H, Yang B, Huang J, Liu G, Chen Q, Zhou G, Chen Q, Li F. Prevalence and quantification of Salmonella contamination in raw chicken carcasses at the retail in China. Food Control. 2014;44:198-202. http:// dx.doi.org/10.1016/j.foodcont.2014.03.050.
Financial Support: Not applicable.

Authors Contributions: Luciano dos Santos Bersot participated in the planning, execution and confection of the manuscript. Cibeli Viana participated in the planning, execution and confection of the manuscript. Mallu Jagnow Sereno participated in the planning, execution and confection of the manuscript. Ana Paula Perin participated in the confection of the manuscript. Vinícius Cunha Barcellos participated in the confection of the manuscript. 